\title{
PATRIMONIO ICONOGRÁFICO: LA FIGURA DEL DEMONIO EN LOS ANDES
}

\author{
Gabriela Benavides de Rivero*
}

Una indagación acerca de la representación del demonio en el Perú del XIX parece un contrasentido. ¿Es que acaso el pensamiento ilustrado y la soberanía de la razón no lograron diluir en la espesura del espacio colonial la presencia de este personaje tan útil y socorrido por la Iglesia evangelizadora y extirpadora, hija de la Contrarreforma? En el nivel de la representación plástica y en el arte en general se puede afirmar que sí y no al mismo tiempo. Sí, porque si hacemos una revisión de la plástica republicana -en donde el neoclásico y el academicismo se imponenla figura luciferina brilla por su ausencia. No, puesto que un breve recorrido por el arte popular -llámese imaginería, máscaras, retablos, tablas o telas-muestra que en este nivel se ha conservado el interés por la representación demoníaca, y ni qué decir de la danza y en general de las fiestas en el universo andino.

\section{EL DEMONIO DECIMONÓNICO}

Satanás, Lucifer, Ángel Caído o simplemente Diablo. Este personaje de la historia sagrada cristiana no desapareció con la revolución francesa ni con el proceso científico y tecnológico posterior. Su imagen continúa en el imaginario occidental, aunque ya no responde exclusivamente al dogma religioso sino que se le ubica también en movimientos intelectuales, culturales y sociales europeos de los siglos XIX y XX. La representación tradicional del demonio ha sido alterada por las críticas de los filósofos de la llustración sin desaparecer del todo, sino adoptando formas más personales, interiorizadas y más íntimamente relacionadas con el hombre, del cual no es más que una faz oscura o máscara vacía'. Dentro de esta definición cabe una gama infinita de posibilidades: motivos, emblemas, mitos, símbolos, pasiones, pulsiones, males $y$ terrores individuales $y$ colectivos.

Aparentemente es una cantera inagotable para los estudios psicoanalíticos marcados a fines del siglo XIX por la fuerte personalidad de Freud. A propósito de ello, hace veinte años apareció uno de esos libros que impactan y son éxito de ventas: Freud et le diable, en el cual Luisa de Urtubey estudia las aventuras satánicas en el pensamiento del padre del psicoanálisis. Pocos estudiosos de la obra del ilustre austríaco sabían que ya en 1896 el diablo se le apareció en un proceso de autoanálisis como un "descenso a los infiernos", coincidiendo con la muerte de su padre. No era un tema nuevo para Freud, quien sostenía que los procesos de histeria y las psicosis en general respondían a una fuerza maligna que se instalaba en los enfermos obligándolos a actuar como si no fueran dueños de sí mismos.

Esta reseña sirve para subrayar cómo este señor del Averno ha pasado de ser un personaje de la cultura y de la religión a un fantasma interior, sin que por ello deje de ser-según afirmación del

- Instituto de Investigaciones, facultad de Ciencias de la Comunicación, Turismo y Psicologia, Universidad de San Martín de Porres, Lima.

1 En este punta sigo básicamente el planteamiento de Robent Muchembled. Une histoire du diable. Xil-XX siécles. Paris, Seuil, pp. 249-297. 
propio Freud- la figura mitológica que mejor encarna los males que el hombre rechaza y que sirve de excusa para justificar toda la negatividad. Negativo y cruel pero muy seductor, ciertamente, debido a su naturaleza de ángel caído y castigado por haber querido ser semejante al Padre. De allí la ambivalencia de amor y odio que produce en las sociedades y en los individuos, que le temen pero lo buscan. Así la figura del diablo a fines del XIX se va recluyendo en las tinieblas del inconsciente en donde pervive como eterna tentación y culpa, siempre en busca de lo prohibido.

Pero esta no es la única posición ideológica del XIX frente a la figura del demonio. Se le considera en ciertos ámbitos intelectuales como objeto de curiosidad, de burla, o simplemente como parte de las supersticiones provenientes de tiempos menos ilustrados. Frente a uno y otro planteamiento la Iglesia católica siguió afirmándose en su mensaje tradicional acerca del Maligno como representante del desorden, de la degeneración moral y el rechazo a la autoridad establecida. En 1879 la encíclica Aeternis patris de León XIII declaró eternamente válida la teología tomista, imponiendo la existencia del demonio como una realidad objetiva.

\section{EL DEMONIO EN EL ARTE}

Satanás ha sido y sigue siendo un personaje de novela y de teatro. Héroe medieval o truhán barroco, lo cierto es que hay una cantidad importante de tragedias, tragicomedias, poesía pastoril y ballets que muestran al demonio en diferentes momentos y aspectos. En el siglo XIX la cultura popular muestra su preferencia por un diablo burlado por los hombres (Belcebú). Respuesta obvia a los temores surgidos de la enseñanza religiosa y de los sermones de la época. Los autores satíricos también toman el tema para sus propias imitaciones y parodias haciendo del diablo un personaje cómico. Otros como William Blake, desviándose de la tradición cristiana pero afirmando la necesidad de creer en algo, afirman que el hombre debe tener una religión y que si no reconoce la de Jesús, al menos debería abrazar la de Satanás².

En general se observa que el demonio está disminuido en una sociedad anticlerical y liberada de una visión trágica de la vida como la decimonónica. Sin embargo es en la tradición popular en donde el personaje sobrevive aunque sea en clave de parodia y haciendo el ridículo. Por otro lado, en los sectores cultos que consumían literatura y arte con esta temática la imagen del diablo era trivial y no obsesiva como en siglos pasados, mucho más cerca de la moda que de la hogue$\mathrm{ra}^{3}$ : una estética mundana del horror que llevaba lo sobrenatural a niveles curiosos y hasta risibles.

\section{EL fANTASMA DEL DEMONIO EN EL PERÚ}

La situación en el Perú no fue muy diferente de la europea en lo tocante a la imposición del pensamiento ilustrado y la actitud frente al terna demoníaco. Los ciudadanos siguen con avidez los acontecimientos y transformaciones en el Viejo Mundo; ya no es España sino son Francia e Inglaterra los paradigmas para una sociedad, en especial para el sector dominante, que quiere alejarse de los antiguos patrones tradicionales para integrarse en lo que se presentaba como lo moderno.

La relación con la Iglesia no fue fácil. Los regulares fueron considerados por los ilustrados un producto de la corrupción debido al carácter privilegiado de las órdenes religiosas, poseedoras de bienes que quedaban al margen del libre comercio y exentas de cualquier tributo a favor del Estado. Esto los etiquetaba como inútiles para la sociedad y su presencia no se justificaba socialmente, salvo un retorno a la pobreza de la iglesia primitiva. De allí el planteamiento de una reforma del clero regular y la desamortización de sus bienes. Este argumento primó para legitimar la expulsión de los jesuitas en 1767 . Fue así como muchos bienes de la Iglesia -y no solo los de la Compañía de Jesús- pasaron a manos privadas.

2 M. Milner. Le Diable dans la litiérature francaise de Cazotte a Baudelaire (1772-1861). Paris, Corti, 1960, 2 vols.

3 Nadie mejor que William Hogarth, pintor satfrico del siglo XVIII, para demostrar este sentimiento trágico de la vida. Se trata de una lámina que título Credulidad, superstición y prejuicio. Observamos el interior de una iglesia con gran cantidad de fieles extasiados por la prédica del pastor que amenaza, desde el elevado púlpito y con la peluca inclinada por tanto entusiasmo, con las liamas del Averno. De sus dedos cuelgan dos monigotes: uno que representa a una bruja, con escoba y gato por supuesto, y el otro al diablo con alas, larga cola y gran tridente. En un rincón se ven copias de los sermones de John Wesley y una traducción al inglés del Malleus Maleficarum, con un barómetro marcando los grados de posesión diabólica. Estos van desde el suicidio hasta la locura, la desesperación, los dolores permanentes, la lujuria, las 
En el campo artístico hay un abandono de los modelos barrocos hispanos para adentrarse en tipos más refinados y de moda. Durante la primera mitad del siglo XIX la pintura peruana estuvo decisivamente influenciada por el romanticismo y el academicismo, mientras que en la segunda hubo una actitud ecléctica, reflejo de las muchas inquietudes y tendencias de los artistas: al lado de los europeizantes $y$ academicistas se colocaron los nacionalistas. El demonio no fue un tema de reflexión en ninguno de los dos momentos. Al igual que en Europa quedó al amparo de algunos curiosos $y$ a veces alucinados literatos, pero de muy pocos plásticos.

\section{DE EXTIRPACIONES Y EXPIACIONES}

El mundo andino ha procesado a su manera la figura del demonio y ha logrado - pienso- resultados bastante parecidos a los que se observa para la cultura popular europea: un diablo que no asusta pero que comunica. ¿Por qué?

Haciendo un poco de historia veremos que cuando la Inquisición inició las grandes persecuciones de los grupos contestatarios medievales, los manuales y doctrinas subrayaban la acción directa del demonio en los movimientos disidentes. Entonces la idolatría se explicaba por la presencia del Maligno. Esto nos suena bastante cercano efectivamente, y es porque con la conquista española llegan a estas tierras contingentes católicos premunidos de dicha cruzada contra el mal y -cómo no- los ídolos prehispánicos debían ser obra del demonio. Para Acosta y la mayoría de los curas doctrineros y extirpadores no cabía la menor duda de que la causa principal de la idolatría era el demonio ${ }^{4}$.

Pero "ni el movimiento de 'extirpación de idolatrías' de los siglos XVI y XVII ni la estructura y el aparato eclesiástico que impera en los Andes desde los albores del siglo XVII, han sido suficientes como para eliminar ritos, creencias y mitos que constituyen aún el fondo del discurso religioso andino"5. Esto explicaría la vigencia de antiguos ritos y expresiones simbólicas propias que han permitido la supervivencia de este pueblo, un tipo de resistencia a las manifestaciones culturales de Occidente.

\section{ARTE POPULAR Y COLECCIONISMO}

El arte popular -como bien señala Francisco Stastny- es una de las más fascinantes y valiosas creaciones de la cultura peruana por sus formas, sus técnicas $y$, fundamentalmente, por la historia contenida en sus imágenes: "El cacharro del alfarero de aldea, el santo de yeso, el amuleto de piedra, la prenda tejida en el telar familiar, son los acompañantes eternos y silenciosos del campesino indio $y$ en sus formas se ha acumulado a través de los siglos una cadena sutil de transformaciones"6.

Se señala que en este arte popular la tradición prehispánica se manifiesta de manera velada: todo lo que era prohibido por la Iglesia y el aparato colonial permanece oculto tras la apariencia engañosa y superficial de corte occidental. Un lenguaje formal y un mensaje explícito conteniendo un bagaje autóctono.

Es pertinente subrayar la labor de los coleccionistas de arte en general y de arte popular en particular porque gracias a su empeño y tesón es posible contar con repositorios bien conservados y puestos a disposición de la colectividad académica y artística para su estudio y exposición?. A propósito de esta investigación he tomado mayor contacto con algunas colecciones de arte popular y el tema del demonio realmente es escaso aunque interesante en las pocas oportunidades en que se presenta.

Una tipología iconográfica muestra fundamentalmente dos imágenes: la de Miguel Arcángel,

\footnotetext{
4 Henrique Urbano. "Estudio preliminar y notas". En Jaseph de Arriaga. La extirpación de la idolarria en el Pirú (1621). Cuzco, Centro Bartolomé de las Casas, 1999, pp. $\mathrm{XI}-\mathrm{C} \times \mathrm{XXI}$.

5 Henrique Urbano. "Simbologia religiosa y conflictos sociales en el sur andino", En Allpanchis, vol. 6 (abril 1976), pp. 161-177.

6 Francisco Stastny. "Dimensión histórica del arte popular". En Historia y Cultura, vol, 12 (tima, 1979), pp. 137-149.

7 El tema del coleccionismo particular es materia de debate hoy en dia. Revisar los antículos pertinentes en los dos volúmenes de Patrimonio cultural del Perú, publicados por el Fondo Editorial del Congreso del Perú, 2000. Asimismo resulta de lo más estimulante el antículo de Alfonso Alfaro. "La lógica del deseo: el coleccionista y sus afa nes". En Artes de México 61 (agosto 2002), pp. 33-43.
} 
el príncipe de la milicia celestial que combate y vence a Luzbel, que aparece en forma de dragón o de ser cornudo; y la de la Virgen Apocalíptica, cuyo origen es el Apocalipsis de San Juan, coronada de estrellas o no, pero siempre sobre un dragón de una o siete cabezas (hay variaciones). En ambos casos hay una evidente influencia de la pintura religiosa oficial que sigue estos patrones iconográficos de origen medieval y los alimenta con las tradiciones renacentista y barroca. Es sabido que el arte popular no obedece a cánones estrictos y se da libertades para interpretar la imagen y sintetizarla de acuerdo con el criterio del artista, del momento o del contexto. Además de estas dos representaciones los demonios son utilizados como complemento en algunos retablos y tablas; existen asimismo algunas figuras interesantes como la de un inca dominando al demonio cual arcángel justiciero.

Una tipología formal o por técnicas informa acerca de la preferencia de los coleccionistas por los retablos y tallas, sobre todo en piedra de Huamanga. La imaginería resalta por su belleza y es evidente la inspiración netamente occidental derivada -como en el caso anterior-de los modelos virreinales o del costumbrismo romántico. El demonio está presente en algunas de estas obras de arte, escasas en realidad ${ }^{8}$. Hay muy poco que decir en cuanto a textiles, cerámica o mates burilados. Sin embargo existe una veta en el arte popular que presenta una iconografía del demonio y que permitirá una explicación mayor. Me refiero a las máscaras en la Colección de Arturo Jiménez Borja que pertenece al Museo de Arte Popular del Instituto Riva-Agüero.

\section{DEMONIO Y MÁSCARA}

La simbología de la máscara vacía comentada al inicio de este ensayo toma cuerpo en este momento gracias a la labor importantísima para el coleccionismo nacional realizada por el doctor Arturo Jiménez Borja, quien manifestaba que este repertorio artístico era fruto de largos años de investigación, recurrentes viajes por el Perú y una preocupación constante por hacerse de máscaras que aparecían en las fiestas populares?

La máscara, con su doble significado de público y privado, comparte con el término "persona" el mismo origen latino: personatus o enmascarado. Cómo somos y cómo nos mostramos ante los demás, espacios privados y espacios públicos, lo auténtico y lo aparente ${ }^{10}$. Todos estos conceptos pueden ser trabajados en torno del tema de las máscaras. En esta oportunidad interesa indagar cómo es que el demonio aparece representado en ellas.

- En Cajabamba se baila la danza de diablos. Diablos con máscaras rosadas y ojos de cristal cubriendo toda la cabeza. Lo único realmente diabólico son los dos cuernos de carnero o chivo.

- En Paucartambo se venera a la mamacha Carmen. En la fiesta aparecen demonios enmascarados conocidos como sajras que acompañan a la virgen en su recorrido pero cubriéndose la cara para no mirarla. Caminan lejos de las andas, por los techos. Se trata de máscaras de yeso, policromadas y con pelucas hechas de crines.

- En Huancabamba las máscaras de diablo en hojalata están presentes en la danza de los diablicos.

- En Puno la diablada es la danza más conocida. Las máscaras son enormes y complicadas. De tela encolada y yeso. Aquí el papel del arcángel Miguel es sobresaliente.

- En Pallasca los diablos van enmascarados en la danza de diablos y san miguelitos. La boca es bastante grande para que se ubique el cigarro.

- En Pomabamba destaca la danza de turcos. Hay un demonio entre los catorce personajes y va al final de la comparsa. Lleva máscara de fieltro viejo.

\footnotetext{
8 José Sabogal. El desván de la imagineria peruana. Lima, Juan Mejía Baca \& P.L. Villanueva, 1956.

9 Arturo fiménez Borja. Máscaras peruanas. Lima, Banco Continen1al, 1996. Para el tema de la fiesta una obra complementaria es la editada por Raúl Romero. Música, danzas y máscaras en los Andes. Lima, Pontificia Universidad Catúlica del Perú, 1998.

10 A propósito de las láminas de Baltasar Jaime Martinez de Companón, cuando Jiménez Boria encuentra la danza de los diablicos o diablada -que es una representación de la lucha entre el Bien (el ángel) y el Mal (7 demonios): los 7 pecados capitales o los siete demonios del Apocalipsis- señala que los indigenas que danzan en ningún momento se muestran como tales, sino que aparecen pieles blancas, bigotes y cejas rubias y hasta ojos claros. La máscara ocuha la verdad.
} 
- En Huaral las máscaras recuerdan las observadas en las ilustraciones de Pancho Fierro.

- En Angasmayo un diablo peculiar -por no llevar cuernos- participa en la danza llamada la legión. nombre que alude a la legión de demonios.

En esta relación aparece una serie de datos relativos a la imagen del demonio y a sus materiales $y$ condiciones formales. Lo más interesante es el contexto festivo en el cual se dan. Los doctrineros observaron que la población andina era muy afecta a la danza y se valieron de las imágenes religiosas expuestas en las celebraciones católicas para la enseñanza y evangelización a través de ellas. La imagen de San Miguel dominando al Anticristo o demonio en forma de serpiente (con una o siete cabezas) fue una de las predilectas. Pero también se convirtió en una expresión bienquerida por los indigenas, por la sencilla razón de ser la serpiente o amaru el espíritu conector con los seres sobrenaturales, restaurador del equilibrio cósmico en el mundo andino. Cabe preguntar si la fuerte presencia de estas máscaras de diablos desde fines del XVIII hasta el siglo $X X$ no obedece fundamentalmente a esta segunda razón. Esta observación descansa en la supuesta supervivencia de los mitos y creencias andinos.

Como señala Jiménez Borja, para un estudio adecuado de las máscaras en el Perú hay que servirse de dos tradiciones: los testimonios culturales prehispánicos y los escritos hispanos. Contrastando las imágenes con el material textual es como se llegará - a través del método iconográfico, especialmente según el diseño de Panofsky - a la construcción de una correcta imagen de lo que significó la máscara de diablos en el Perú. En el primer caso existe evidencia en los vasos moche con representaciones mitológicas y zoomorfas; también se puede recurrir a las imágenes recogidas por Guamán Poma en su descripción de las festividades de los cuatro suyos. Un tercer elemento corresponde a las máscaras funerarias, confeccionadas en hueso, cerámica, madera, cobre y oro. Desde que los españoles llegaron a estas tierras empezaron a recoger $y$ publicar información acerca de la costumbre andina de colocarse máscaras por un motivo ritual o festivo: Pedro Pizarro, Francisco de Ávila; también lo hicieron Garcilaso de la Vega y Guamán Poma. En el siglo XVIII el obispo de Trujillo Martínez de Compañón registró a través de acuarelas las costumbres de su diócesis y queda muy clara la preferencia por las danzas de enmascarados: imágenes de venados, osos, gallinazos, conejos, guacamayos y otros.

Por otra parte, la población hispana, de antigua tradición en la confección y uso de máscaras, se valió de festividades como la de Corpus Christi o toros para mostrar su arte. Tanto los $\mathrm{Li}$ bros de Cabildo de Lima como los Diarios de Suardo y Mugaburo informan de los pormenores de las fiestas religiosas limeñas, en especial la de Corpus con sus Gigantes y Cabezudos.

Pero de todas las danzas festivas hay una en particular que Martínez de Compañón observó con detenimiento $y$ que nos servirá para la última parte de este informe: la danza de los diablicos, conocida como diablada en el sur andino.

\section{LA DIABLADA ANDINA}

Este festejo popular tiene un correlato en la denominada endiablada espan̄ola: "festejo y función jocosa en que muchos se disfrazaban con máscaras y figuras ridiculas de diablos". El origen de ella en tanto festejo público de los demonios se remonta por lo menos a la segunda mitad del siglo XVI, cuando adquiere un carácter ritual al incorporarse a las procesiones del Corpus Christi en Barcelona"1. Para 1583 hay documentación que señala que durante la procesión del Corpus, en el tema de las representaciones del Antiguo Testamento, "aparece una Creación del mundo, en la que 24 diablos batallaban a pie contra 20 ángeles con espada, capitaneados por San Miguel". En otro momento se observa el entremés sobre el Paraíso y el Infierno, con la batalla de San Miguel y los ángeles buenos contra Lucifer y sus secuaces. Las imágenes preferidas son las de diablos y ángeles en batalla, y la del castillo del infierno y el dragón. 
¿Qué tanto de esta tradición queda en el XIX peruano después del proceso de evangelización y en pleno contexto ilustrado y anticlerical? Pues ni tan ilustrada ni anticlerical es la zona altoperuana en donde se origina esta fiesta denominada diablada. En 1789 la Virgen se aparece milagrosamente a un bandido herido, quien muy agradecido pinta un fresco con la imagen de la señora sobre un muro de la bocamina del cerro en que se produjo el milagro, pues su alma también se salvó. Se trataba de una bellísima imagen de la Virgen de la Candelaria y el lugar se denominó desde entonces "Socavón de la Virgen". Esta advocación se celebra el 2 de febrero, muy cerca de los carnavales. Se juntaron las fechas $y$ en los tres días de festejo los mineros festejaban a la Virgen disfrazándose de diablos. Aquí se observan dos datos que es pertinente subrayar. Uno: una Virgen cuya fiesta coincide con los carnavales (fiesta pagana por la primera cosecha de papas). Dos: se le celebra con danzas de diablos. Hay que agregar que este bandido, de acuerdo con la tradición oral, solo robaba a los ricos.

A inicios del XIX apareció un "Relato de los diablos", de autor desconocido pero atribuible a un clérigo culto. Al poco tiempo la peregrinación a las faldas del cerro por comerciantes de la ciudad fue cosa común. Las danzas de diablos se sistematizaron en las conocidas diabladas.

"Los diablos tradicionales portan una víbora en la mano, y mientras que sus antiguas máscaras (en hojalata o escayola) poseían rasgos humanos con sapos entre los dientes y lagartijas en las mejillas -fauna menor y en corto número-se pidió a los mascareros que incluyesen nuevos elementos; y así aparecen los dragones de tres cabezas, con ojos saltones y grandes orejas, rodeados por abundantes fieras"12.

Es evidente que a una tradición de "diablos" prehispánicos se superpone la imagen cristiana del demonio. La Virgen y la serpiente o amaru tienen en común la condición de intercesores entre los hombres y los seres divinos: léase Cristo en el primer caso y Hanan Pacha en el segundo.
¿De dónde proviene la imagen de un "diablo" prehispánico? El Uku Pacha es el mundo de abajo, tenebroso y bajo el dominio de un genio maléfico denominado Huari por los habitantes aymaras de esta región del lago Titicaca. Este genio del mal hace daño con el engaño, enviando serpientes, sapos y lagartos a sus enemigos; es además el señor de los cerros ricos en metales de Oruro. Quien lo vence en reiteradas oportunidades es la "Virgen del Socavón", que se enfrenta a los enemigos infernales o del inframundo. Por ello las máscaras con sapos y lagartos van asumiendo rasgos occidentales. En la tradición judeocristiana la Virgen del Apocalipsis aplasta al dragón y las grandes orejas son los cuernos característicos de la representación medieval de Satanás.

\section{A MODO DE CONCLUSIÓN}

Durante el siglo XIX la figura del demonio decae en la iconografía universal debido al avance de la ideología ilustrada y científica. El Perú no se aleja mucho de este desarrollo, principalmente en el nivel de la cultura oficial y urbana. En el nivel rural la situación es diferente y es posible encontrar una cantidad estimable de producción en arte popular que sigue presentando al demonio como parte importante del imaginario religioso.

Dentro del conjunto de arte popular las máscaras de diablos ofrecen la oportunidad de un análisis un poco más profundo, debido a la variedad y cantidad en comparación con otros tipos artísticos.

La diablada en tanto fiesta, pero en especial la máscara de diablo como elemento que confiere naturaleza y sentido a este acontecimiento, sirve para entender cómo se ha ido construyendo la imagen del demonio en el arte popular, por lo menos en la regiónc altoandina.

La presencia de elementos católicos y prehispánicos hacen de este arte popular un claro exponente del llamado arte mestizo. 
La lectura iconológica parca esta construcción del demonio descansa en los altributos consignados a partir de las tradiciones, $y$ a la interpretación del comportamiento de los aclores en la fiesta y el porqué de la misma. Es evidente que hay una yuxtaposición de una festividad católica sobre otra andina. ¿Quién la hizo? El dominio español es evidente a través de la Madre de Dios y sin embargo el diablo es el protagonista, es quien destaca y hace gala de su poder. Hay un interés por demostrarlo. Un diablo identificado con el amaru. Esto explicaría la gran aceptación de la diablada y en general de cualquier expresión icónica del demonio dentro de la población rural campesina.

En este caso se cumple el sentido dual de la máscara. ¿Dónde se encuentra lo auténtico y dónde lo aparente? Esta pregunta queda pendiente para una próxima investigación. 